Article

\title{
Processing Analysis of Nanoparticle Filled PTFE: Restrictions and Limitations of High Temperature Production
}

\author{
Levente Ferenc Tóth ${ }^{1,2}\left(\mathbb{D}\right.$, Patrick De Baets ${ }^{1,3}$ and Gábor Szebényi ${ }^{2, *(\mathbb{C})}$ \\ 1 Soete Laboratory, Department of Electromechanical, Systems and Metal Engineering, Ghent University, \\ Technologiepark Zwijnaarde 46, B-9052 Zwijnaarde, Belgium; levente.toth@ugent.be (L.F.T.); \\ patrick.debaets@ugent.be (P.D.B.) \\ 2 Department of Polymer Engineering, Faculty of Mechanical Engineering, Budapest University of Technology \\ and Economics, Múegyetem rkp. 3, H-1111 Budapest, Hungary \\ 3 FlandersMake@UGent-Core lab EEDT-DC, Technologiepark Zwijnaarde 131, B-9052 Zwijnaarde, Belgium \\ * Correspondence: szebenyi@pt.bme.hu; Tel.: +36-1-463-1466
}

Received: 13 August 2020; Accepted: 4 September 2020; Published: 8 September 2020

\begin{abstract}
In this research work, unfilled and monofilled polytetrafluoroethylene (PTFE) were investigated. The applied fillers were graphene, alumina $\left(\mathrm{Al}_{2} \mathrm{O}_{3}\right)$, boehmite alumina (BA80) and hydrotalcite (MG70). Graphene and $\mathrm{Al}_{2} \mathrm{O}_{3}$ are already known in the literature as potential fillers of PTFE, while BA80 and MG70 are novel fillers in PTFE. Materials were produced by room temperature pressing - free sintering method with a maximum sintering temperature of $370^{\circ} \mathrm{C}$. The mass loss and decomposition analyses were carried out by thermogravimetric analysis (TGA) in two different ways. The first was a sensitivity analysis to gain a better view into the sintering process at $370{ }^{\circ} \mathrm{C}$ maximal temperature. The second was a heating from $50{ }^{\circ} \mathrm{C}$ up to $1000{ }^{\circ} \mathrm{C}$ for a full-scale decomposition analysis. BA80 is a suitable filler for PTFE, as most of its functional groups still existed after the sintering process. Both PTFE and $\mathrm{Al}_{2} \mathrm{O}_{3}$ had high thermal stability. However, when $\mathrm{Al}_{2} \mathrm{O}_{3}$ was incorporated in PTFE, a remarkable mass loss was observed during the sintering process, which indicated that the decomposition of PTFE was catalysed by the $\mathrm{Al}_{2} \mathrm{O}_{3}$ filler. The observed mass loss of the $\mathrm{Al}_{2} \mathrm{O}_{3}$-filled PTFE was increased, as the $\mathrm{Al}_{2} \mathrm{O}_{3}$ content or the applied dwelling time at a $370{ }^{\circ} \mathrm{C}$ sintering temperature increased.
\end{abstract}

Keywords: nanoparticle-filled PTFE; thermal stability; free sintering; processing analysis

\section{Introduction}

Nanoparticles are widely used as reinforcement materials in thermoplastics, as they can achieve relevant improvements, e.g., mechanical, thermal and wear properties [1-8]. Polytetrafluoroethylene (PTFE), which is a semicrystalline thermoplastic, gains high importance in sliding and rolling applications, because it can work as both a matrix material and a solid lubricant [9]. PTFE has high thermal stability, excellent chemical resistance, a low coefficient of friction and good self-lubricating properties compared to other semicrystalline thermoplastics. Well-known limitations are relatively low mechanical properties and low wear resistance, which can be enhanced with the application of reinforcements such as fibres and micro- or nanoparticles [10-12]. Focusing on nanoparticles, graphene and alumina $\left(\mathrm{Al}_{2} \mathrm{O}_{3}\right)$ can improve the wear resistance of PTFE by two to three orders of magnitude [13-15]. Due to the promising results of graphene- and $\mathrm{Al}_{2} \mathrm{O}_{3}$-filled PTFE, nowadays a remarkable amount of research work related to these materials is available.

Besides material properties, another relevant factor for the wear behaviour of filled PTFE is the potential chemical reactions between the given fillers, the matrix material and the metal counterfaces. In the literature, it is hypothesised that PTFE molecular chains are subjected to mechanical chain 
scission during the wear process, forming carboxyl functional groups $(-\mathrm{COOH})$ at the end of the broken PTFE molecular chains [14,16]. For example, in case of $\mathrm{Al}_{2} \mathrm{O}_{3}$ fillers, these in situ formed carboxyl functional groups of PTFE can participate in complex formation with $\mathrm{Al}_{2} \mathrm{O}_{3}$ nanoparticles [16]. Fillers with functional groups can be promising wear resistance improvers, as they can initiate a higher number of complex formation due to their extra functional groups, which can have a positive influence on wear resistance [17]. Based on this hypothesis, boehmite alumina (BA80) and hydrotalcite (MG70) fillers are potential filler candidates, as they have high numbers of functional groups. PTFE in combination with these fillers has not yet been extensively investigated. Karger-Kocsis et al. reported in their review that boehmite does improve not only the wear resistance but also the Young's modulus, toughness, creep resistance and thermal stability of polymer matrices [18,19].

The high processing temperature of PTFE can, however, be a challenge for those potential fillers shown above. A well-known production method for PTFE is the room temperature pressing-free sintering technique. The applied maximum sintering temperature is between 360 and $380^{\circ} \mathrm{C}$, which can be high enough to result in the decomposition of filler materials. Therefore, in case of applications of novel additives, a proper sensitivity analysis is always required. The functional groups of BA80 and MG70 fillers can be decomposed at the sintering temperature; therefore, the full sintering process is analysed with TGA to gain detailed knowledge about the thermal stability and the decomposition of the fillers at the sintering temperature.

It is reported that at a high temperature $\left(\sim 800^{\circ} \mathrm{C}\right)$ the following reaction takes place between PTFE and $\mathrm{Al}_{2} \mathrm{O}_{3}$ (Equation (1)) [20]:

$$
1.5 / n\left(\mathrm{C}_{2} \mathrm{~F}_{4}\right)_{n}+\mathrm{Al}_{2} \mathrm{O}_{3} \rightarrow 2 \mathrm{AlF}_{3}+3 \mathrm{CO}
$$

A question here is whether the range of sintering temperature can be high enough for the initiation of the mentioned reaction.

The present research work introduces the thermal analysis of graphene, $\mathrm{Al}_{2} \mathrm{O}_{3}, \mathrm{BA} 80$ and MG70-filled PTFE composites, focusing on the sensitivity (thermal stability) and decomposition analysis during the sintering process. In the literature, a comprehensive sensitivity analysis during the sintering process of graphene- and $\mathrm{Al}_{2} \mathrm{O}_{3}$-filled PTFE is rarely reported. As a result, we are lacking a general production protocol and an overview of production limitations.

\section{Materials and Methods}

\subsection{Materials}

The used PTFE powder was $3 \mathrm{M}^{\mathrm{TM}}$ Dyneon ${ }^{\mathrm{TM}} \mathrm{TFM}^{\mathrm{TM}} 1700$ with a $25 \mu \mathrm{m}$ average particle size, produced by the 3M Company (Minnesota Mining and Manufacturing Company, Maplewood, MN, USA). The applied graphene was $\mathrm{xGnP}^{\circledR}$ Graphene Nanoplatelets Grade $\mathrm{M}$ from XG Sciences (Lansing, MI, USA). The used $1015 \mathrm{WW}$ alpha $\mathrm{Al}_{2} \mathrm{O}_{3}$ with $99.5 \%$ purity was produced by Nanostructured \& Amorphous Materials Inc. (Houston, TX, USA). The nanoparticle sizes were between 27 and $43 \mathrm{~nm}$. The applied boehmite alumina (BA80) was Disperal ${ }^{\circledR} 80$ from Sasol (Johannesburg, South Africa) with a $35 \mu \mathrm{m}$ average particle size and an $80 \mathrm{~nm}$ average crystallite size. The $\mathrm{Al}_{2} \mathrm{O}_{3}$ content of $\mathrm{BA} 80$ was $80 \%$. Pural ${ }^{\circledR}$ MG70 hydrotalcite $\left(\mathrm{Mg}_{6} \mathrm{Al}_{2} \mathrm{CO}_{3}(\mathrm{OH})_{16} \cdot 4\left(\mathrm{H}_{2} \mathrm{O}\right)\right.$, MG70) from Sasol (Johannesburg, South Africa) with a $\sim 45 \mu \mathrm{m}$ average particle size had a double-layered metal hydroxide structure including magnesium and aluminium hydroxides (70:30 $\mathrm{wt} \%$, respectively).

\subsection{Production Protocol and Properties of the Unfilled and Filled PTFE Samples}

The composition of the produced unfilled and filled PTFE materials can be seen in Table 1. The applied production technique was room temperature pressing - free sintering method. The PTFE and filler powders were firstly blended by intensive dry mechanical stirring, which is a less hazardous and more environment-friendly alternative than the solvent blending method. Stirring was provided by a rotating blade grinder (power: $180 \mathrm{~W}$ ), and the stirring time was $30 \mathrm{~s}$. Pressing was carried out 
with a Zwick Z250 universal tester at room temperature. The pressing speed was $2 \mathrm{~mm} / \mathrm{min}$, until a 12.5 MPa pressure was reached. Subsequently, $3 \mathrm{~min}$ of dwelling time was held at the same level of pressure. The sintering procedure was carried out in air atmosphere. The sintering cycle was shown as following: a heating rate of $90^{\circ} \mathrm{C} / \mathrm{h}$ to increase the temperature from room temperature to $370{ }^{\circ} \mathrm{C}$, a dwelling time of $2 \mathrm{~h}$ at a $370^{\circ} \mathrm{C}$ maximum temperature and a $30{ }^{\circ} \mathrm{C} / \mathrm{h}$ cooling rate. All the applied fillers were incorporated with a $4,8,16$, or $30 \mathrm{wt} \%$ filler content.

Table 1. The developed neat polytetrafluoroethylene (PTFE) and PTFE-based materials.

\begin{tabular}{cccc}
\hline Materials & Matrix & Filler & Filler Content (wt \%) \\
\hline PTFE & PTFE & - & - \\
PTFE/graphene-4 & PTFE & graphene & 4 \\
PTFE/graphene-8 & PTFE & graphene & 8 \\
PTFE/graphene-16 & PTFE & graphene & 16 \\
PTFE/graphene-30 & PTFE & graphene & 30 \\
PTFE/ $\mathrm{Al}_{2} \mathrm{O}_{3}-4$ & PTFE & alumina $\left(\mathrm{Al}_{2} \mathrm{O}_{3}\right)$ & 4 \\
PTFE/ $\mathrm{Al}_{2} \mathrm{O}_{3}-8$ & PTFE & alumina $\left(\mathrm{Al}_{2} \mathrm{O}_{3}\right)$ & 8 \\
PTFE/ $\mathrm{Al}_{2} \mathrm{O}_{3}-16$ & PTFE & alumina $\left(\mathrm{Al}_{2} \mathrm{O}_{3}\right)$ & 16 \\
PTFE/ $\mathrm{Al}_{2} \mathrm{O}_{3}-30$ & PTFE & alumina $\left(\mathrm{Al}_{2} \mathrm{O}_{3}\right)$ & 30 \\
PTFE/BA80-4 & PTFE & boehmite alumina (BA80) & 4 \\
PTFE/BA80-8 & PTFE & boehmite alumina (BA80) & 8 \\
PTFE/BA80-16 & PTFE & boehmite alumina (BA80) & 16 \\
PTFE/BA80-30 $/$ PAFE & boehmite alumina (BA80) & 30 \\
PTFE/MG70-4 & PTFE & hydrotalcite (MG70) & 4 \\
PTFE/MG70-8 & PTFE & hydrotalcite (MG70) & 8 \\
PTFE/MG70-16 & PTFE & hydrotalcite $(M G 70)$ & 16 \\
PTFE/MG70-30 & PTFE & hydrotalcite (MG70) & 30 \\
\hline
\end{tabular}

\subsection{Thermal and Decomposition Analysis}

\subsubsection{Thermogravimetric Analysis (TGA)}

TGA was carried out with a TA Instruments Q500 device (New Castle, DE, USA) in nitrogen or air atmosphere, depending on the type of test. The purge gas was nitrogen with a $40 \mathrm{~mL} / \mathrm{min}$ flow. The samples were placed in platinum pans and tested in a $60 \mathrm{~mL} / \mathrm{min}$ nitrogen or air flow.

\subsubsection{Fourier-Transform Infrared Spectroscopy (FTIR)}

FTIR analyses were carried out by a Bruker Tensor 37 FTIR spectrometer (Billerica, MA, USA) with a deuterated triglycine sulfate (DTGS) detector and a Specac Golden Gate single reflection monolithic diamond attenuated total reflection (ATR, Orpington, UK) sampling system. The applied spectroscopic transmission range was between 600 and $4000 \mathrm{~cm}^{-1}$ with a $4 \mathrm{~cm}^{-1}$ resolution in wavenumber.

\section{Results and Discussion}

\subsection{Decomposition and Thermal Stability Analysis of the Applied Fillers}

\subsubsection{Decomposition of Graphene}

Figure 1 presents the mass loss of graphene as a function of the temperature, while Table 2 shows the residual mass $\left(\mathrm{m}_{\mathrm{r}}\right)$ of graphene measured by TGA. Significant decomposition was recorded only at temperatues from $343{ }^{\circ} \mathrm{C}$, where $1 \%$ of the graphene mass was lost (Figure 1a). The decomposition procedure can be separated into two steps. The first was between $\sim 343$ and $500{ }^{\circ} \mathrm{C}$ and came from the decomposition of the amorphous carbon content [21], while the second step was in the range of $\sim 570-800{ }^{\circ} \mathrm{C}$ and came from the decomposition of the structured graphene. The total mass loss of graphene was $\sim 100 \%$. The detected mass loss at the first step was $\sim 19 \%$ (Figure 1a). 


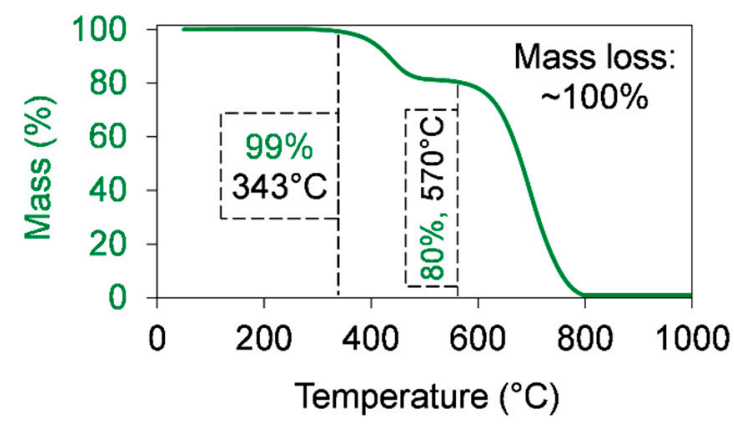

(a)

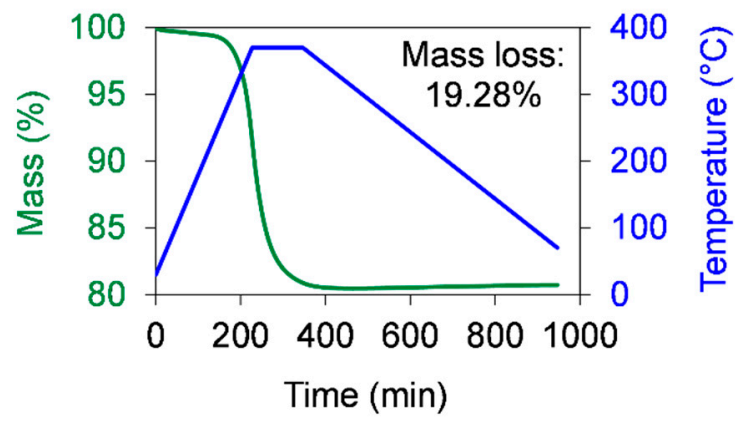

(b)

Figure 1. Thermal stability of graphene in air atmosphere measured by thermogravimetric analysis (TGA). (a) The mass loss of graphene as a function of the temperature when a $10^{\circ} \mathrm{C} / \mathrm{min}$ heating rate was used to increase the temperature up to $1000{ }^{\circ} \mathrm{C}$. (b) The mass loss of graphene as a function of the time during the simulation of a sintering cycle. The sintering cycle was shown as following: A $1.5^{\circ} \mathrm{C} / \mathrm{min}\left(90^{\circ} \mathrm{C} / \mathrm{h}\right)$ heating rate was used to increase the temperature from room temperature up to $370{ }^{\circ} \mathrm{C}$. Then, a dwelling time of $2 \mathrm{~h}$ at $370{ }^{\circ} \mathrm{C}$ was used. After that, the temperature was cooled down at a $0.5^{\circ} \mathrm{C} / \mathrm{min}\left(30^{\circ} \mathrm{C} / \mathrm{h}\right)$ cooling rate.

The decomposition of graphene was analysed during the sintering cycle as well. The sintering process was simulated by TGA (Figure $1 \mathrm{~b}$ ) by applying a temperature range between 30 and $370{ }^{\circ} \mathrm{C}$ at a $1.5^{\circ} \mathrm{C} / \mathrm{min}\left(90^{\circ} \mathrm{C} / \mathrm{h}\right)$ heating rate and a $0.5^{\circ} \mathrm{C} / \mathrm{min}\left(30^{\circ} \mathrm{C} / \mathrm{h}\right)$ cooling rate. The dwelling time at $370{ }^{\circ} \mathrm{C}$ was $2 \mathrm{~h}$. The measured mass loss was $19.28 \%$, which means that during the sintering cycle most of the amorphous carbon content decomposed.

\subsubsection{Decomposition of $\mathrm{Al}_{2} \mathrm{O}_{3}$}

Figure 2 and Table 2 show the mass loss of $\mathrm{Al}_{2} \mathrm{O}_{3}$ measured by TGA. The total mass loss was $2.69 \%$ (Figure 2a). According to the manufacturer's datasheet, the purity of the used $\mathrm{Al}_{2} \mathrm{O}_{3}$ is around $99.5 \%$. In other words, $\sim 0.5 \%$ contaminants can be found in this filler. In the range of $200-240{ }^{\circ} \mathrm{C}$, a higher mass loss rate was recorded, which can come from the adsorbed humidity and from some contaminants. At around $590^{\circ} \mathrm{C}$, a slight mass increase can be seen, which was supposed to come from the oxidation of some contaminants in the filler.

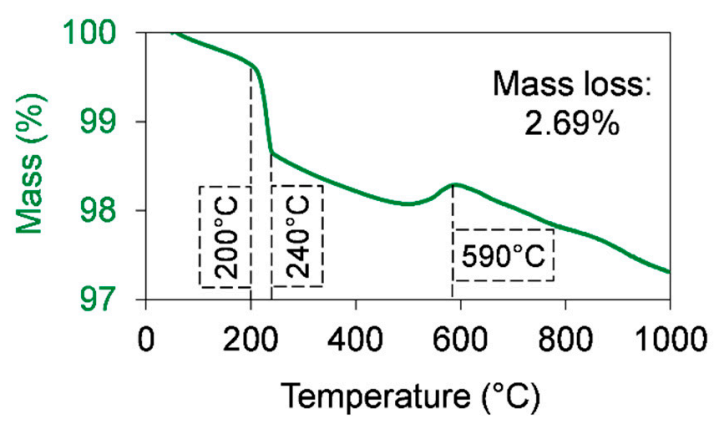

(a)

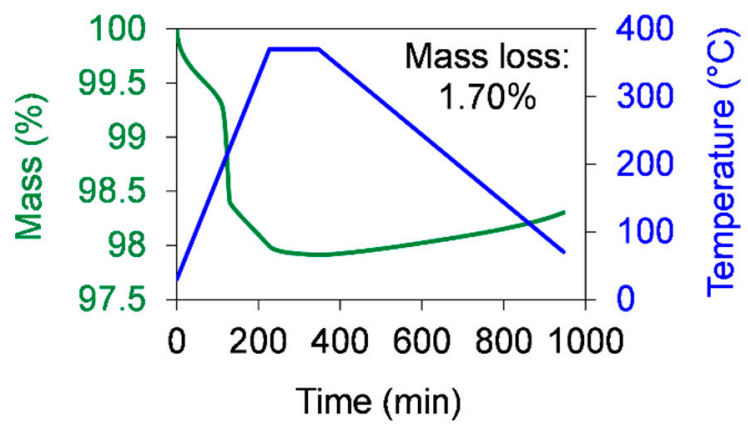

(b)

Figure 2. Thermal stability of alumina in air atmosphere measured by TGA. (a) The mass loss of graphene as a function of the temperature when a $10{ }^{\circ} \mathrm{C} / \mathrm{min}$ heating rate was used to increase the temperature up to $1000^{\circ} \mathrm{C}$. (b) The mass loss of graphene as a function of the time during the simulation of a sintering cycle. The sintering cycle was shown as following: A $1.5^{\circ} \mathrm{C} / \mathrm{min}\left(90^{\circ} \mathrm{C} / \mathrm{h}\right)$ heating rate was used to increase the temperature from room temperature up to $370{ }^{\circ} \mathrm{C}$. Then, a dwelling time of $2 \mathrm{~h}$ at $370{ }^{\circ} \mathrm{C}$ was used. After that, the temperature was cooled down at a $0.5^{\circ} \mathrm{C} / \mathrm{min}\left(30^{\circ} \mathrm{C} / \mathrm{h}\right)$ cooling rate. 
Table 2. Residual mass $\left(\mathrm{m}_{\mathrm{r}}\right)$ of the filled PTFE after the sintering process and at $1000{ }^{\circ} \mathrm{C}$ measured by TGA.

\begin{tabular}{ccc}
\hline Materials & $\mathbf{m}_{\mathbf{r}}$ after Sintering $\mathbf{( \% )}$ & $\mathbf{m}_{\mathbf{r}}$ at $\mathbf{1 0 0 0}{ }^{\circ} \mathbf{C ~ ( \% )}$ \\
\hline PTFE & 99.99 & $\sim 0$ \\
graphene & 80.72 & $\sim 0$ \\
$\mathrm{Al}_{2} \mathrm{O}_{3}$ & 98.30 & 97.31 \\
$\mathrm{BA} 80$ & 95.35 & 83.35 \\
MG70 & 64.83 & 55.09 \\
\hline
\end{tabular}

The decomposition of $\mathrm{Al}_{2} \mathrm{O}_{3}$ was also measured during the sintering cycle. The sintering process was simulated by TGA (Figure 2b) by applying a temperature range between 30 and $370{ }^{\circ} \mathrm{C}$ at a $1.5^{\circ} \mathrm{C} / \mathrm{min}\left(90^{\circ} \mathrm{C} / \mathrm{h}\right)$ heating rate and a $0.5^{\circ} \mathrm{C} / \mathrm{min}\left(30^{\circ} \mathrm{C} / \mathrm{h}\right)$ cooling rate. The dwelling time at $370{ }^{\circ} \mathrm{C}$ was $2 \mathrm{~h}$. The measured mass loss was $1.70 \%$. The FTIR spectrum of the reference (unsintered) $\mathrm{Al}_{2} \mathrm{O}_{3}$ was measured. The FTIR spectra of $\mathrm{Al}_{2} \mathrm{O}_{3}$ at temperatures up to $370{ }^{\circ} \mathrm{C}$ (simulation of sintering process) and those of $\mathrm{Al}_{2} \mathrm{O}_{3}$ at temperatures up to $1000{ }^{\circ} \mathrm{C}$ were measured by TGA. No differences were found in these FTIR spectra (Figure 3).

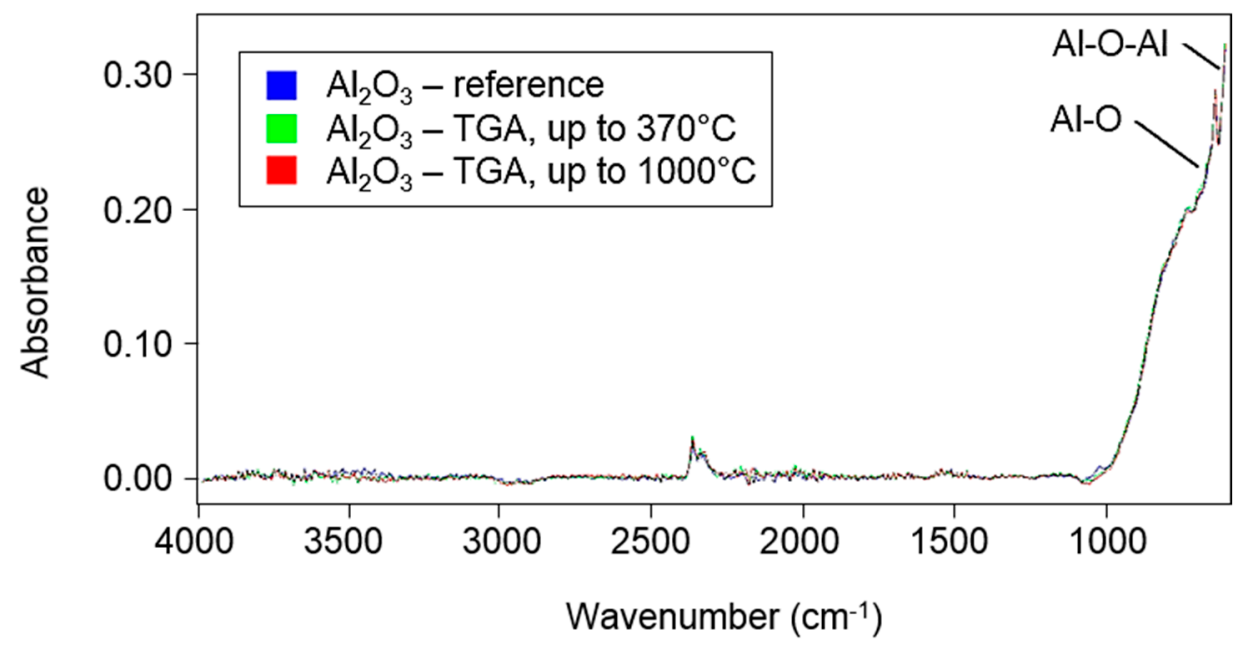

Figure 3. Fourier-transform infrared spectroscopy (FTIR) spectra of the reference $\mathrm{Al}_{2} \mathrm{O}_{3}$ (in blue), $\mathrm{Al}_{2} \mathrm{O}_{3}$ measured by TGA at temperatures up to $370{ }^{\circ} \mathrm{C}$ (i.e., the simulation of a sintering process) (in green) and $\mathrm{Al}_{2} \mathrm{O}_{3}$ measured by TGA at temperatures up to $1000^{\circ} \mathrm{C}$ (in red).

\subsubsection{Decomposition of BA80 (Aluminium Hydroxide Oxide- $\mathrm{AlO}(\mathrm{OH})$ )}

Theoretically, BA80 decomposes into alumina and water according to the following chemical reaction (Equation (2)):

$$
2 \mathrm{AlO}(\mathrm{OH}) \rightarrow \mathrm{Al}_{2} \mathrm{O}_{3}+\mathrm{H}_{2} \mathrm{O} .
$$

The mass percentage of $\mathrm{H}_{2} \mathrm{O}$ is the theoretical mass loss, which can be measured by TGA. To get information about this theoretical value, the atomic masses of aluminium $(27 D a)$, oxygen $(16 D a)$ and hydrogen $(1 \mathrm{Da})$ have to been considered. In this way, the mass of the molecules in Equation (2) is introduced by Equation (3):

$$
120(D a) \rightarrow 102(D a)+18(D a) .
$$

The theoretical mass loss can be calculated from the mass ratio of $\mathrm{H}_{2} \mathrm{O}$ and $2 \mathrm{AlO}(\mathrm{OH})$ (Equation (4)):

$$
18 / 120=0.15 \rightarrow 15 \%
$$


According to Equations (2)-(4), the theoretical mass percentage of water was $15 \%$. The mass loss measured by TGA was in the range of the calculated theoretical mass loss. The measured $\mathrm{H}_{2} \mathrm{O}$ percentage value was $16.65 \%$ (Figure $4 \mathrm{a}$ and Table 2 ), which was slightly higher than the theoretical value. This difference comes from the humidity of and contaminants in the analysed sample. In Figure $4 \mathrm{a}$, it can be seen that the decomposition of BA80 started to be relevant at temperatures from $288^{\circ} \mathrm{C}$, which was significantly lower than the applied sintering temperature $\left(370^{\circ} \mathrm{C}\right)$. The initiation of the decomposition was defined at a $1 \%$ mass loss, similarly to the introduced previous analyses. TGA measurement was performed with a heat hold at $200{ }^{\circ} \mathrm{C}$ to get information about the content of humidity and about these contaminants, which can vaporise under $200{ }^{\circ} \mathrm{C}$. The total mass loss was $16.68 \%$, which correlated well to the $16.65 \%$ mass loss (Figure 4a) presented earlier. After a $10 \mathrm{~h}$ dwelling time at $200{ }^{\circ} \mathrm{C}\left(10^{\circ} \mathrm{C} / \mathrm{min}\right.$ heating rate to increase the temperature from room temperature up to $200^{\circ} \mathrm{C}$ and a $10^{\circ} \mathrm{C} / \mathrm{min}$ heating rate to increase the temperature from $200^{\circ} \mathrm{C}$ up to $1000{ }^{\circ} \mathrm{C}$ ), the mass loss was only $0.75 \%$, and the rest mass loss was $15.93 \%$ between 200 and $1000{ }^{\circ} \mathrm{C}$. The percentage of the decomposed material during the sintering cycle was investigated by simulating a sintering process with TGA (Figure $4 \mathrm{~b}$ ), applying a temperature ramp between 30 and $370{ }^{\circ} \mathrm{C}$ at a $1.5^{\circ} \mathrm{C} / \min \left(90^{\circ} \mathrm{C} / \mathrm{h}\right)$ heating rate and a $0.5^{\circ} \mathrm{C} / \mathrm{min}$ $\left(30^{\circ} \mathrm{C} / \mathrm{h}\right)$ cooling rate. The dwelling time at $370{ }^{\circ} \mathrm{C}$ was $2 \mathrm{~h}$. The measured mass loss was $4.65 \%$, which was around $28 \%$ (calculated by $4.65 / 16.65$ ) of the total measured mass loss (Figure 4a). It means that, although some of the $\mathrm{OH}$ functional groups decomposed during the sintering cycle, most of them persisted. This can be beneficial in the wear process according to the introduced hypothesis, which is related to the complex formation with the carboxyl groups of PTFE chain ends during wear. To confirm the persistence of $\mathrm{OH}$ functional groups, the samples taken out from TGA were also analysed by FTIR.

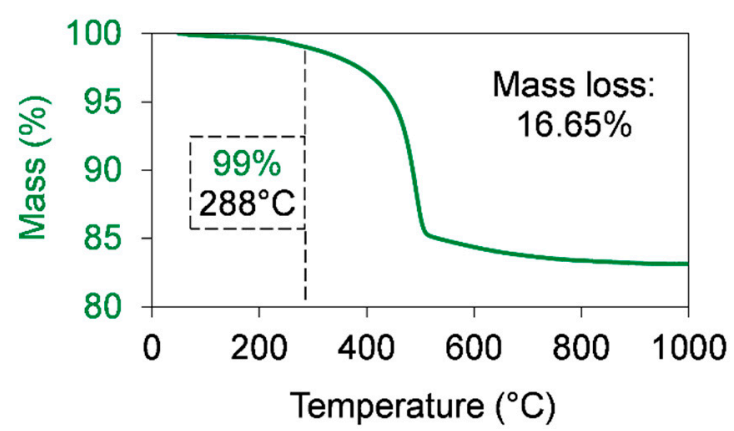

(a)

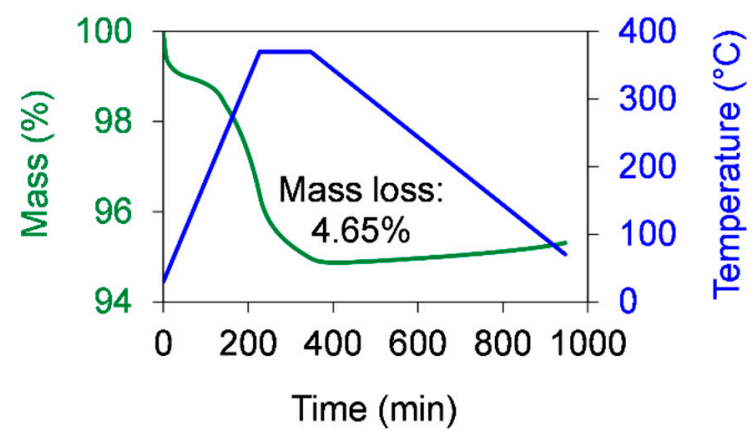

(b)

Figure 4. Thermal stability of boehmite alumina in air atmosphere measured by TGA. (a) The mass loss of graphene as a function of the temperature when a $10^{\circ} \mathrm{C} / \mathrm{min}$ heating rate was used to increase the temperature up to $1000^{\circ} \mathrm{C}$. (b) The mass loss of graphene as a function of the time during the simulation of a sintering cycle. The sintering cycle was shown as following: A $1.5^{\circ} \mathrm{C} / \mathrm{min}\left(90^{\circ} \mathrm{C} / \mathrm{h}\right)$ heating rate was used to increase the temperature from room temperature up to $370{ }^{\circ} \mathrm{C}$. Then, a $2 \mathrm{~h}$ dwelling time at $370{ }^{\circ} \mathrm{C}$ was used. After that, the temperature was cooled down at a $0.5^{\circ} \mathrm{C} / \mathrm{min}\left(30^{\circ} \mathrm{C} / \mathrm{h}\right)$ cooling rate.

Figure 5 shows the FTIR spectra for the samples of the reference (unsintered) BA80, of BA80 measured by TGA at temperatures up to $370^{\circ} \mathrm{C}$ (simulation of sintering process) and of BA80 measured by TGA at temperatures up to $1000^{\circ} \mathrm{C}$. The latter two samples were the same, which were analysed by TGA. Two significant peaks attributed to -OH bonds were detected in the range of $3000-3400 \mathrm{~cm}^{-1}$, which is in agreement with the literature [22]. These peaks can be seen in both of the reference and the sintered samples. These spectra confirmed that most of the $\mathrm{OH}$ functional groups survived in the sintering process, but not in the TGA test at a temperature of $1000^{\circ} \mathrm{C}$. 


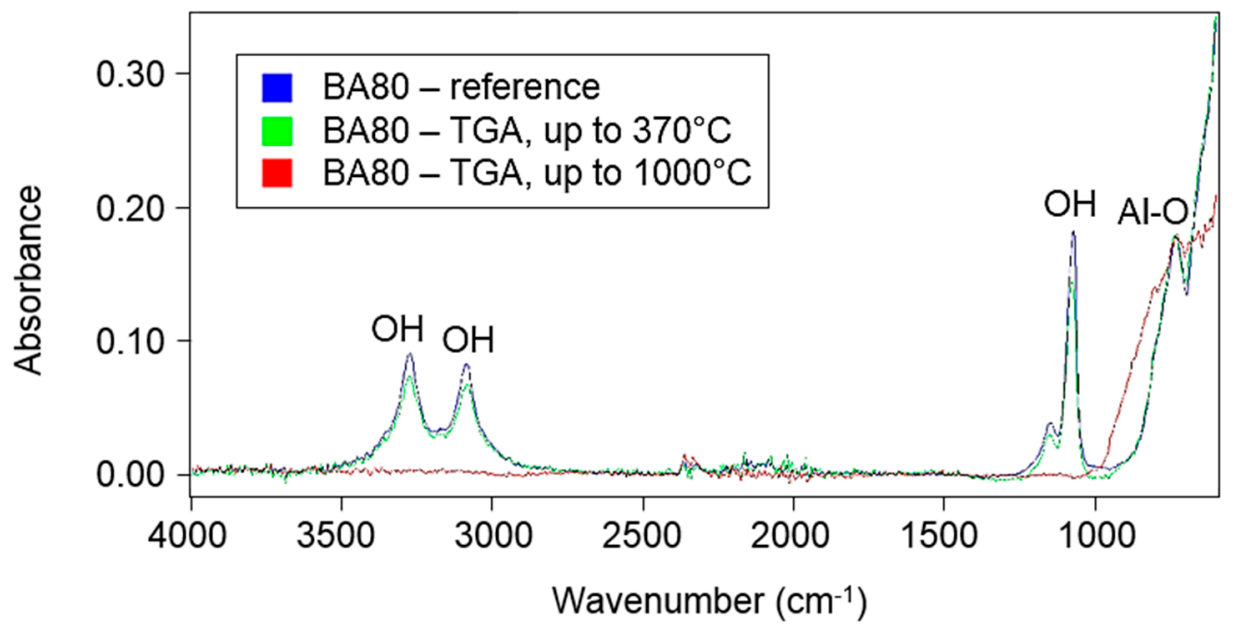

Figure 5. FTIR spectra of the reference BA80 (in blue), BA80 measured by TGA at temperatures up to $370{ }^{\circ} \mathrm{C}$ (i.e., simulation of a sintering process) (in green) and BA80 measured by TGA at temperatures up to $1000{ }^{\circ} \mathrm{C}$ (in red).

\subsubsection{Decomposition of MG70}

Figure 6 and Table 2 shows the mass percentages and the residual mass $\left(\mathrm{m}_{\mathrm{r}}\right)$ of MG70 measured by TGA. Significant decomposition was recorded at temperatures from $104{ }^{\circ} \mathrm{C}$, where $1 \%$ of the graphene mass was lost (Figure 6a). The total mass loss during the MG70 decomposition was $44.91 \%$ (Figure 6a), while this value in case of the simulated sintering procedure was $35.17 \%$ (Figure $6 \mathrm{~b}$ ). It means that the mass loss during the sintering process was around $78 \%$ of the full mass loss of MG70. Due to the observed high decomposition of MG70 during the sintering process, this material is not a promising filler for high temperature production of PTFE.

Figure 7 compares the FTIR spectrum of the reference (unsintered) MG70, that of MG70 measured by TGA at temperatures up to $370{ }^{\circ} \mathrm{C}$ (i.e., simulation of a sintering process) and that of MG70 measured by TGA at temperatures up to $1000{ }^{\circ} \mathrm{C}$. The peaks of the sintered MG70 already changed significantly compared to those of the reference material.

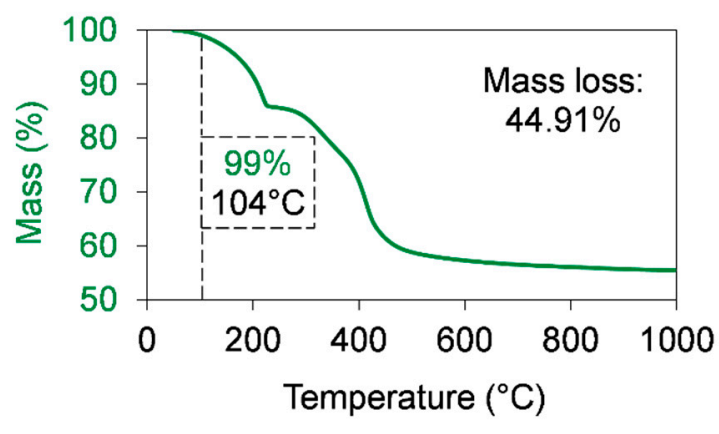

(a)

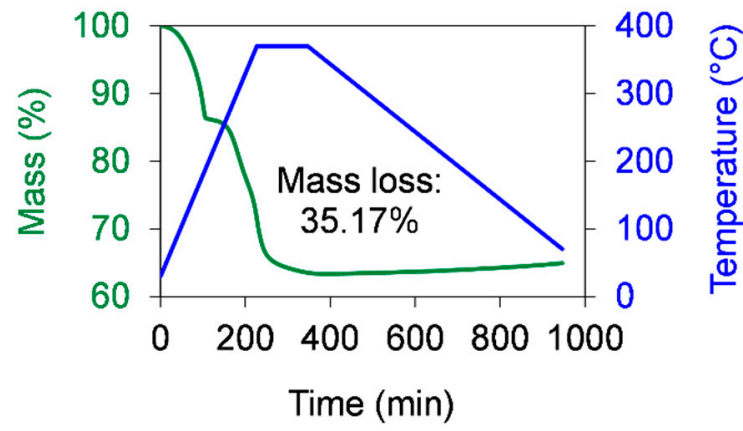

(b)

Figure 6. Thermal stability of MG70 measured by TGA in air atmosphere. (a) The mass loss of graphene as a function of the temperature when a $10^{\circ} \mathrm{C} / \mathrm{min}$ heating rate was used to increase the temperature up to $1000^{\circ} \mathrm{C}$. (b) The mass loss of graphene as a function of the time during the simulation of a sintering cycle. The sintering cycle was shown as following: A $1.5^{\circ} \mathrm{C} / \mathrm{min}\left(90^{\circ} \mathrm{C} / \mathrm{h}\right)$ heating rate was used to increase the temperature from room temperature up to $370{ }^{\circ} \mathrm{C}$. Then, a $2 \mathrm{~h}$ dwelling time at $370{ }^{\circ} \mathrm{C}$ was used. After that, the temperature was cooled down at a $0.5^{\circ} \mathrm{C} / \mathrm{min}\left(30^{\circ} \mathrm{C} / \mathrm{h}\right)$ cooling rate. 


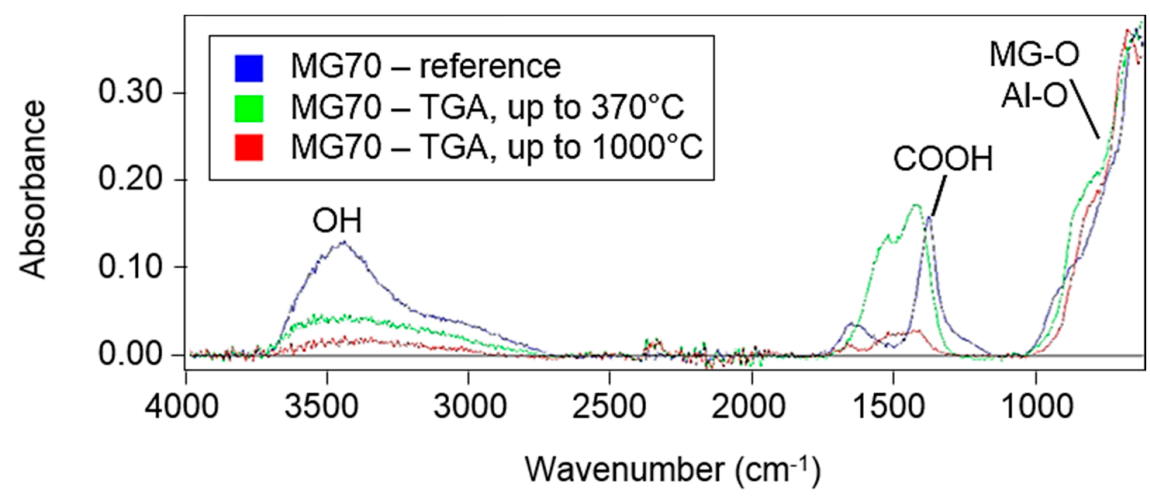

Figure 7. FTIR spectra of the reference MG70 (in blue), MG70 measured by TGA at temperatures up to $370{ }^{\circ} \mathrm{C}$ (i.e., simulation of the sintering process) (in green) and MG70 measured by TGA at temperatures up to $1000^{\circ} \mathrm{C}$ (in red).

\subsection{Decomposition and Thermal Stability Analysis of the Developed Unfilled/Filled Materials}

\subsubsection{Decomposition of the Unfilled and Filled PTFE during the Full Sintering Process}

Tables 2 and 3 show the residual mass $\left(m_{r}\right)$ in case of the neat fillers and the filled PTFE. The sintering process involved a $90{ }^{\circ} \mathrm{C} / \mathrm{h}$ heating rate to increase the temperature up to $370{ }^{\circ} \mathrm{C}$, a $2 \mathrm{~h}$ dwelling time at a $370{ }^{\circ} \mathrm{C}$ temperature and a $30^{\circ} \mathrm{C} / \mathrm{h}$ cooling rate to decrease the temperature to room temperature. The residual mass was evaluated at the beginning of the hold time, at the beginning of the cooling (after $2 \mathrm{~h}$ heat dwelling) and after the final sintering process. As shown in Table 3, the theoretical sample mass was calculated from the measured residual mass of the neat PTFE and the neat fillers. The highlighted numbers in Table 3 (Section 4) reflected these final $\mathrm{m}_{\mathrm{r}}$ values, where the difference between theoretical and measured values was higher than $1 \%$.

Table 3. Residual mass $\left(\mathrm{m}_{\mathrm{r}}\right)$ during the sintering process measured by TGA.

\begin{tabular}{|c|c|c|c|}
\hline Materials & $\begin{array}{c}\mathrm{m}_{\mathrm{r}} \text { at the Beginning of Hold Time } \\
\text { at } 370^{\circ} \mathrm{C}(\%)\end{array}$ & $\begin{array}{c}\mathrm{m}_{\mathrm{r}} \text { at the Beginning of Cooling } \\
\text { at } 370^{\circ} \mathrm{C}(\%)\end{array}$ & $\begin{array}{l}\text { Final } \mathrm{m}_{\mathrm{r}} \text { after } \\
\text { Sintering }(\%)\end{array}$ \\
\hline \multicolumn{4}{|c|}{ Section 1: Experimental values based on the neat PTFE and the neat fillers measured by TGA } \\
\hline PTFE & 100.00 & 99.97 & 99.99 \\
\hline graphene & 91.35 & 80.93 & 80.72 \\
\hline $\mathrm{Al}_{2} \mathrm{O}_{3}$ & 98.03 & 97.96 & 98.30 \\
\hline BA80 & 96.37 & 95.01 & 95.35 \\
\hline MG70 & 71.26 & 63.42 & 64.83 \\
\hline \multicolumn{4}{|c|}{ Section 2: Experimental values based on the filled PTFE measured by TGA } \\
\hline PTFE/graphene-30 & 97.40 & 92.63 & 92.15 \\
\hline PTFE/graphene-16 & 98.65 & 95.92 & 95.60 \\
\hline PTFE/graphene- 8 & 99.04 & 97.63 & 97.62 \\
\hline PTFE/graphene-4 & 99.59 & 98.86 & 98.86 \\
\hline $\mathrm{PTFE} / \mathrm{Al}_{2} \mathrm{O}_{3}-30$ & 99.22 & 96.28 & 95.35 \\
\hline PTFE $/ \mathrm{Al}_{2} \mathrm{O}_{3}-16$ & 99.83 & 98.64 & 98.20 \\
\hline $\mathrm{PTFE} / \mathrm{Al}_{2} \mathrm{O}_{3}-8$ & 99.73 & 98.92 & 98.66 \\
\hline $\mathrm{PTFE} / \mathrm{Al}_{2} \mathrm{O}_{3}-4$ & 99.64 & 99.25 & 99.17 \\
\hline PTFE/BA80-30 & 99.07 & 97.96 & 97.91 \\
\hline PTFE/BA80-16 & 99.39 & 98.85 & 98.66 \\
\hline PTFE/BA80-8 & 99.65 & 99.34 & 99.32 \\
\hline PTFE/BA80-4 & 99.75 & 99.48 & 99.45 \\
\hline PTFE/MG70-30 & 91.51 & 89.58 & 89.54 \\
\hline PTFE/MG70-16 & 95.19 & 93.93 & 94.11 \\
\hline PTFE/MG70-8 & 97.71 & 97.10 & 96.97 \\
\hline PTFE/MG70-4 & 98.58 & 98.23 & 98.32 \\
\hline
\end{tabular}


Table 3. Cont.

\begin{tabular}{|c|c|c|c|}
\hline Materials & $\begin{array}{c}\mathrm{m}_{\mathrm{r}} \text { at the Beginning of Hold Time } \\
\text { at } 370^{\circ} \mathrm{C}(\%)\end{array}$ & $\begin{array}{c}\mathrm{m}_{\mathrm{r}} \text { at the Beginning of Cooling } \\
\text { at } 370^{\circ} \mathrm{C}(\%)\end{array}$ & $\begin{array}{l}\text { Final } \mathrm{m}_{\mathrm{r}} \text { after } \\
\text { Sintering }(\%)\end{array}$ \\
\hline \multicolumn{4}{|c|}{ Section 3: Theoretical values calculated based on the filler contents and $m_{r}$ in Section 1} \\
\hline PTFE/graphene-30 & 97.41 & 94.26 & 94.21 \\
\hline PTFE/graphene-16 & 98.62 & 96.92 & 96.91 \\
\hline PTFE/graphene- 8 & 99.31 & 98.45 & 98.45 \\
\hline PTFE/graphene-4 & 99.65 & 99.21 & 99.22 \\
\hline $\mathrm{PTFE} / \mathrm{Al}_{2} \mathrm{O}_{3}-30$ & 99.41 & 99.37 & 99.48 \\
\hline $\mathrm{PTFE} / \mathrm{Al}_{2} \mathrm{O}_{3}-16$ & 99.68 & 99.65 & 99.72 \\
\hline $\mathrm{PTFE} / \mathrm{Al}_{2} \mathrm{O}_{3}-8$ & 99.84 & 99.81 & 99.85 \\
\hline $\mathrm{PTFE} / \mathrm{Al}_{2} \mathrm{O}_{3}-4$ & 99.92 & 99.89 & 99.92 \\
\hline PTFE/BA80-30 & 98.91 & 98.48 & 98.60 \\
\hline PTFE/BA80-16 & 99.42 & 99.18 & 99.25 \\
\hline PTFE/BA80-8 & 99.71 & 99.57 & 99.62 \\
\hline PTFE/BA80-4 & 99.85 & 99.77 & 99.80 \\
\hline PTFE/MG70-30 & 91.38 & 89.01 & 89.44 \\
\hline PTFE/MG70-16 & 95.40 & 94.12 & 94.36 \\
\hline PTFE/MG70-8 & 97.70 & 97.05 & 97.18 \\
\hline PTFE/MG70-4 & 98.85 & 98.51 & 98.58 \\
\hline \multicolumn{4}{|c|}{ Section 4: Difference between the theoretical and measured values (= Section 3 - Section 2 ) } \\
\hline PTFE/graphene-30 & 0.01 & 1.63 & $2.06 *$ \\
\hline PTFE/graphene-16 & -0.03 & 1.00 & $1.31 *$ \\
\hline PTFE/graphene-8 & 0.27 & 0.82 & 0.83 \\
\hline PTFE/graphene-4 & 0.06 & 0.35 & 0.36 \\
\hline $\mathrm{PTFE} / \mathrm{Al}_{2} \mathrm{O}_{3}-30$ & 0.19 & 3.09 & $4.13 *$ \\
\hline $\mathrm{PTFE} / \mathrm{Al}_{2} \mathrm{O}_{3}-16$ & -0.15 & 1.01 & $1.52 *$ \\
\hline PTFE $/ \mathrm{Al}_{2} \mathrm{O}_{3}-8$ & 0.11 & 0.89 & 1.19 * \\
\hline $\mathrm{PTFE} / \mathrm{Al}_{2} \mathrm{O}_{3}-4$ & 0.28 & 0.64 & 0.75 \\
\hline PTFE/BA80-30 & -0.16 & 0.52 & 0.69 \\
\hline PTFE/BA80-16 & 0.03 & 0.33 & 0.59 \\
\hline PTFE/BA80-8 & 0.06 & 0.23 & 0.30 \\
\hline PTFE/BA80-4 & 0.10 & 0.29 & 0.35 \\
\hline PTFE/MG70-30 & -0.13 & -0.58 & -0.10 \\
\hline PTFE/MG70-16 & 0.21 & 0.19 & 0.25 \\
\hline PTFE/MG70-8 & -0.01 & -0.05 & 0.21 \\
\hline PTFE/MG70-4 & 0.27 & 0.28 & 0.26 \\
\hline
\end{tabular}

As can be seen, there was a gap between the theoretical and the measured residual masses of the developed composites. In case of graphene- and $\mathrm{Al}_{2} \mathrm{O}_{3}$-filled samples, the measured residual mass was higher than it was expected from the mass losses of the PTFE and the given fillers. The most significant difference was observed in case of the PTFE $/ \mathrm{Al}_{2} \mathrm{O}_{3}-30$ sample. These higher values indicated that there was an interaction between the graphene or $\mathrm{Al}_{2} \mathrm{O}_{3}$ filler and PTFE, and consequently, a higher decomposition was observed compared to those of the neat additives.

\subsubsection{Extended Heat Dwelling (10 h)}

Decomposition analysis of PTFE composites was performed by simulating a sintering process with a $10 \mathrm{~h}$ dwelling time at a maximum temperature of $370{ }^{\circ} \mathrm{C}$. The heating and cooling rates were the same as in the original sintering process. The residual masses was observed in Table 4 at the start of the dwelling time $(0 \mathrm{~h})$ and after 2, 4, 6, 8 and $10 \mathrm{~h}$ dwelling times. With this long interval, it was possible to get a more detailed insight into the stability of the composites during the sintering process. As can be seen in Tables 4 and 5, the masses of graphene-, $\mathrm{Al}_{2} \mathrm{O}_{3}$ - and BA80-filled samples were significantly decreased with the increasing dwelling time during the full heating dwelling time of $10 \mathrm{~h}$. In contrast 
with this, only slight mass losses were observed in case of the unfilled PTFE and the neat $\mathrm{Al}_{2} \mathrm{O}_{3}$, which were only $0.07 \%$ and $0.13 \%$ during the $10 \mathrm{~h}$ dwelling time at a $370{ }^{\circ} \mathrm{C}$ temperature, respectively. The PTFE/MG70 samples showed moderate mass decreases in the $10 \mathrm{~h}$ interval, because most of the decomposition occurred at the heating period before the dwelling time. The most significant influence of the dwelling time for the decomposition was observed in case of the PTFE $/ \mathrm{Al}_{2} \mathrm{O}_{3}-30$ sample, where the mass loss was $16.60 \%$. The theoretical value based on the neat materials and the filler contents was only $0.09 \%$ (Table 5), which means that the rest of the material loss came from an interaction between PTFE and $\mathrm{Al}_{2} \mathrm{O}_{3}$. These results clearly showed that, in case of the applied fillers, a longer dwelling time led to a higher decomposed material mass, which can have a negative effect on the final material properties. The largest difference between the measured and theoretical values was observed for the $\mathrm{Al}_{2} \mathrm{O}_{3}$-filled samples in case of 4, 8, 16 and $30 \mathrm{wt} \%$ filler contents as well (highlighted numbers in Table 5).

Table 4. Residual masses during different dwelling times at $370{ }^{\circ} \mathrm{C}$ in air atmosphere measured by TGA.

\begin{tabular}{|c|c|c|c|c|c|c|}
\hline \multirow{2}{*}{ Materials } & \multicolumn{6}{|c|}{ Residual Mass $\left(m_{r}\right)$ at an Elapsed Dwelling Time $(\%)$} \\
\hline & $\mathbf{O h}$ & $2 \mathrm{~h}$ & $4 \mathrm{~h}$ & $6 \mathrm{~h}$ & $8 \mathrm{~h}$ & $10 \mathrm{~h}$ \\
\hline PTFE & 99.96 & 99.92 & 99.91 & 99.90 & 99.90 & 99.89 \\
\hline graphene & 90.80 & 80.37 & 79.57 & 79.33 & 79.19 & 79.09 \\
\hline $\mathrm{Al}_{2} \mathrm{O}_{3}$ & 97.92 & 97.81 & 97.79 & 97.79 & 97.79 & 97.79 \\
\hline BA 80 & 96.65 & 95.32 & 94.83 & 94.46 & 94.14 & 93.84 \\
\hline MG70 & 69.18 & 64.17 & 63.44 & 62.99 & 62.80 & 62.61 \\
\hline PTFE/graphene-30 & 97.17 & 92.33 & 90.97 & 90.27 & 89.70 & 89.19 \\
\hline PTFE $/ \mathrm{Al}_{2} \mathrm{O}_{3}-30$ & 99.30 & 96.37 & 92.85 & 89.40 & 86.00 & 82.70 \\
\hline PTFE/BA80-30 & 98.83 & 97.38 & 95.93 & 94.74 & 93.68 & 92.73 \\
\hline PTFE/MG70-30 & 90.85 & 88.90 & 88.47 & 88.15 & 87.89 & 87.66 \\
\hline PTFE/graphene-16 & 98.39 & 95.65 & 94.93 & 94.46 & 94.04 & 93.64 \\
\hline PTFE/Al $\mathrm{Al}_{2} \mathrm{O}_{3}-16$ & 99.65 & 97.84 & 96.04 & 94.38 & 92.84 & 91.38 \\
\hline PTFE/BA80-16 & 99.40 & 98.65 & 97.75 & 96.85 & 95.98 & 95.14 \\
\hline PTFE/MG70-16 & 95.27 & 94.16 & 93.91 & 93.72 & 93.56 & 93.43 \\
\hline PTFE/graphene- 8 & 99.19 & 97.79 & 97.25 & 97.10 & 96.90 & 96.71 \\
\hline PTFE/ $/ \mathrm{Al}_{2} \mathrm{O}_{3}-8$ & 99.73 & 98.79 & 97.77 & 96.86 & 95.97 & 95.12 \\
\hline PTFE/BA80-8 & 99.71 & 99.26 & 98.69 & 98.10 & 97.49 & 96.89 \\
\hline PTFE/MG70-8 & 97.54 & 96.93 & 96.79 & 96.70 & 96.62 & 96.56 \\
\hline PTFE/graphene-4 & 99.61 & 99.02 & 98.83 & 98.65 & 98.47 & 98.26 \\
\hline PTFE $/ \mathrm{Al}_{2} \mathrm{O}_{3}-4$ & 99.87 & 99.44 & 99.02 & 98.58 & 98.16 & 97.73 \\
\hline PTFE/BA80-4 & 99.76 & 99.31 & 98.86 & 98.41 & 98.00 & 97.61 \\
\hline PTFE/MG70-4 & 98.73 & 98.41 & 98.33 & 98.27 & 98.21 & 98.16 \\
\hline
\end{tabular}

Regarding the potential interaction between PTFE and $\mathrm{Al}_{2} \mathrm{O}_{3}$, the FTIR spectra of the sintered PTFE $/ \mathrm{Al}_{2} \mathrm{O}_{3}-30$ sample after a $10 \mathrm{~h}$ heat dwelling time did not indicate the existence of $\mathrm{AlF}_{3}$ bonds (Equation (1)). Therefore, the introduced reaction was supposed not to take place at the sintering circumstances. A potential explanation for the measured high mass loss of the $\mathrm{Al}_{2} \mathrm{O}_{3}$-filled samples can be a catalysing effect of the $\mathrm{Al}_{2} \mathrm{O}_{3}$ filler on the decomposition of the PTFE material.

\subsection{Decomposition and Thermal Stability Analysis of the Developed Unfilled and Filled Materials}

The decomposition analyses of the developed unfilled and filled PTFE in air and nitrogen atmosphere are shown in Figures 8 and 9, respectively. All the filled materials included fillers in a nominal content of $4 \mathrm{wt} \%$. The residual mass percentages in air atmosphere correlated well with the TGA measurements of the neat additives (Figures 1a, 2a, 4a and 6a). In case of the neat PTFE and PTFE/graphene-4, the observed decomposition was $100 \%$. In PTFE/graphene-4, an approximately $3 \%$ 
mass loss was observed in the range of $600-800{ }^{\circ} \mathrm{C}$, which correlated well with the second step of the graphene decomposition (Figure 1a).

Table 5. Mass losses during a dwelling time of $10 \mathrm{~h}$ at $370{ }^{\circ} \mathrm{C}$ in air atmosphere measured by TGA. The theoretical values in column 3 were calculated based on the basis of filler contents and the mass loss of the neat PTFE and the neat fillers. Column 4 introduces the difference between the theoretical (column 3) and measured values (column 2).

\begin{tabular}{|c|c|c|c|}
\hline Materials & $\begin{array}{l}\text { Mass Loss }(0-10 \mathrm{~h}) \\
\text { Measured by TGA }(\%)\end{array}$ & $\begin{array}{l}\text { Theoretical Values of } \\
\text { Mass Loss }(0-10 \mathrm{~h})(\%)\end{array}$ & $\begin{array}{l}\text { Mass Loss }(0-10 \text { h) Difference }(\%) \\
\text { (Measured Value-Theoretical Value) }\end{array}$ \\
\hline PTFE & 0.07 & - & - \\
\hline graphene & 11.71 & - & - \\
\hline $\mathrm{Al}_{2} \mathrm{O}_{3}$ & 0.13 & - & - \\
\hline BA 80 & 2.81 & - & - \\
\hline MG70 & 6.57 & - & - \\
\hline PTFE/graphene-30 & 7.98 & 3.56 & 4.42 \\
\hline PTFE $/ \mathrm{Al}_{2} \mathrm{O}_{3}-30$ & 16.60 & 0.09 & $16.51 *$ \\
\hline PTFE/BA80-30 & 6.10 & 0.89 & 5.21 \\
\hline PTFE/MG70-30 & 3.19 & 2.02 & 1.17 \\
\hline PTFE/graphene-16 & 4.75 & 1.93 & 2.82 \\
\hline PTFE/ $\mathrm{Al}_{2} \mathrm{O}_{3}-16$ & 8.27 & 0.08 & $8.19 *$ \\
\hline PTFE/BA80-16 & 4.26 & 0.51 & 3.75 \\
\hline PTFE/MG70-16 & 1.84 & 1.11 & 0.73 \\
\hline PTFE/graphene- 8 & 2.48 & 1.00 & 1.48 \\
\hline PTFE/ $/ \mathrm{Al}_{2} \mathrm{O}_{3}-8$ & 4.61 & 0.07 & 4.54 * \\
\hline PTFE/BA 80-8 & 2.82 & 0.29 & 2.53 \\
\hline PTFE/MG70-8 & 0.98 & 0.59 & 0.39 \\
\hline PTFE/graphene-4 & 1.35 & 0.54 & 0.81 \\
\hline PTFE/ $/ \mathrm{Al}_{2} \mathrm{O}_{3}-4$ & 2.14 & 0.07 & $2.07 *$ \\
\hline PTFE/BA80-4 & 2.15 & 0.18 & 1.97 \\
\hline PTFE/MG70-4 & 0.57 & 0.33 & 0.24 \\
\hline
\end{tabular}

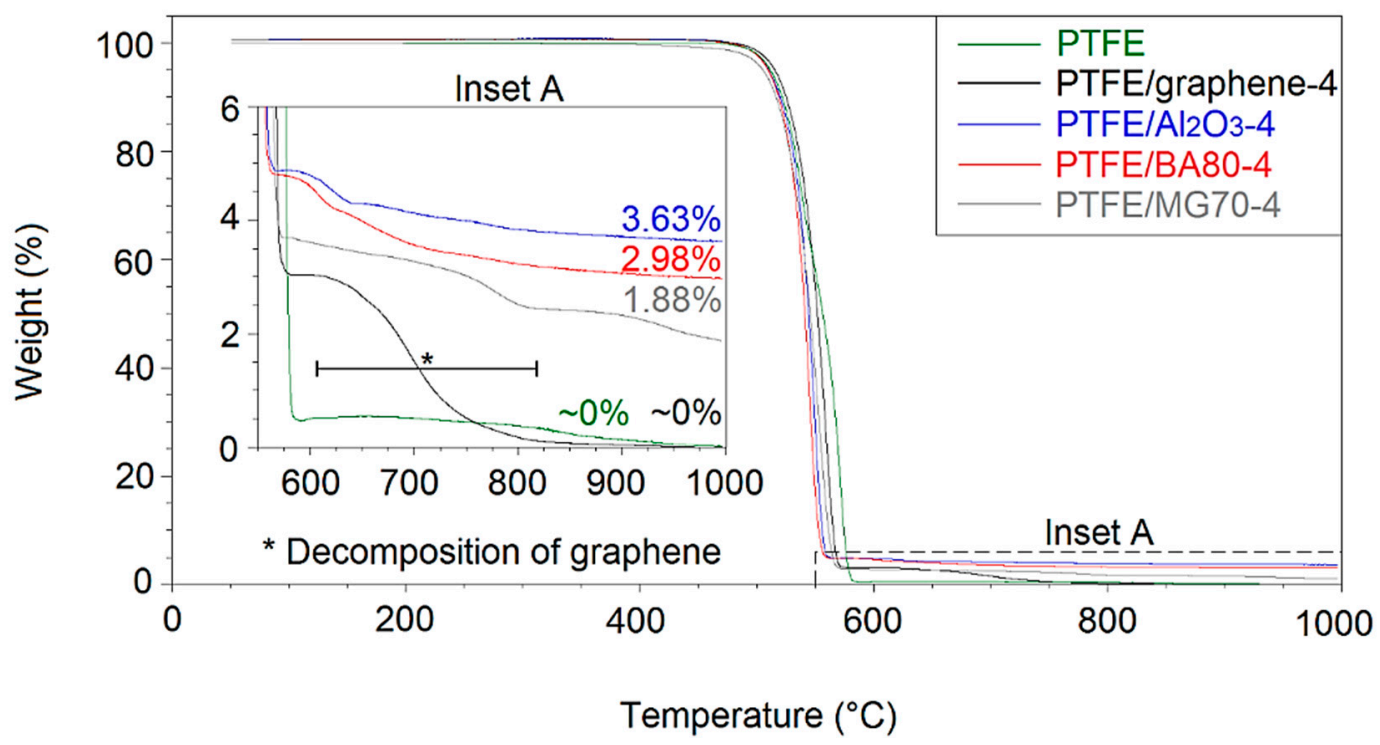

Figure 8. Decomposition analysis of the filled and unfilled PTFE in air atmosphere measured by TGA. 


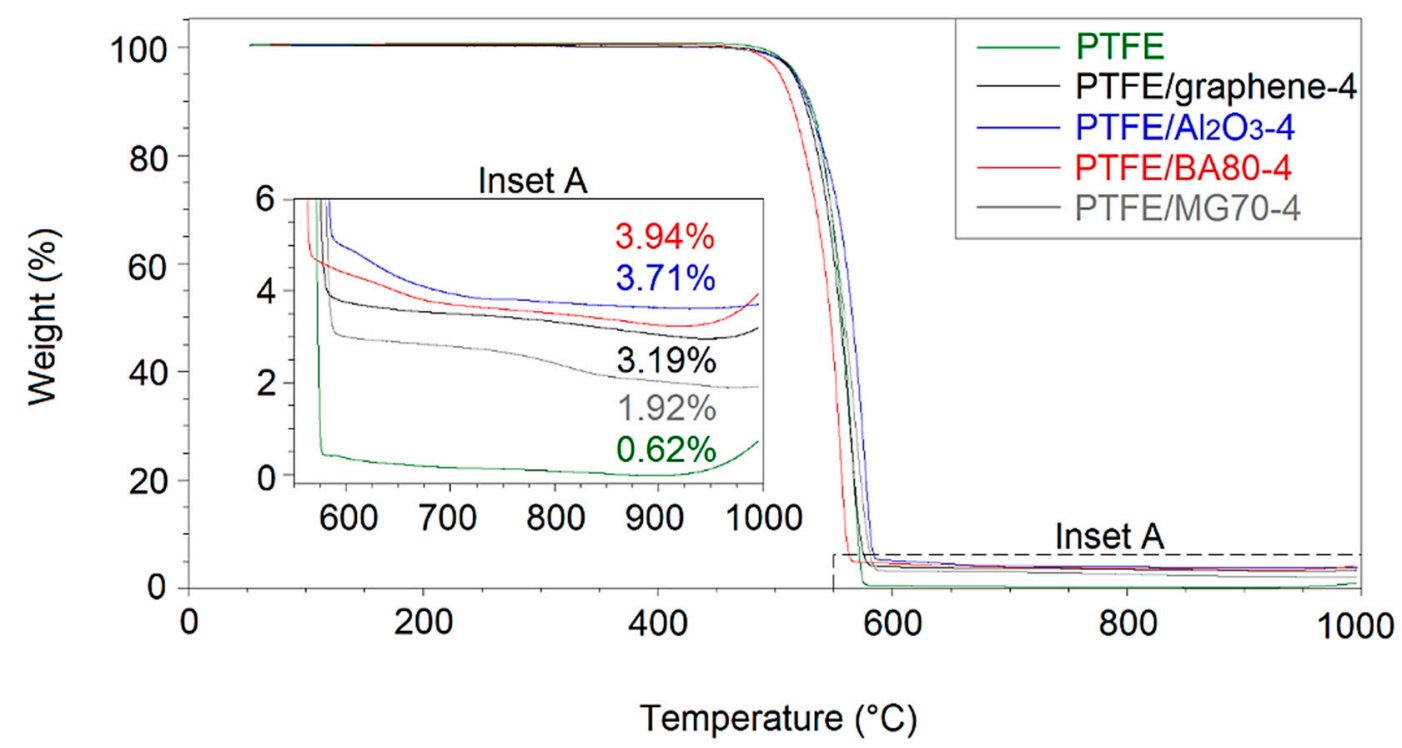

Figure 9. Decomposition analysis of the filled and unfilled PTFE in nitrogen atmosphere measured by TGA.

Tables 6 and 7 show the temperatures measured at 1\%,10\% and 50\% mass losses for all analysed materials in air and nitrogen atmosphere, respectively. The temperature of all the additives decreased at $1 \%$ and $10 \%$ mass losses with respect to that of the reference neat PTFE, except the PTFE/graphene-4 sample, where the temperature at a $10 \%$ mass loss was higher than in case of the neat PTFE. These results indicated lower thermal stability in both air and nitrogen atmosphere.

Table 6. The temperatures in case of $1 \%, 10 \%$ and $50 \%$ mass losses in air atmosphere measured by TGA.

\begin{tabular}{cccc}
\hline Materials & $\begin{array}{c}\text { Temperature at a 1\% } \\
\text { Mass Loss }\left({ }^{\circ} \mathbf{C}\right)\end{array}$ & $\begin{array}{c}\text { Temperature at a 10\% } \\
\text { Mass Loss }\left({ }^{\circ} \mathbf{C}\right)\end{array}$ & $\begin{array}{c}\text { Temperature at a 50\% } \\
\text { Mass Loss }\left({ }^{\circ} \mathbf{C}\right)\end{array}$ \\
\hline PTFE & 489.9 & 521.2 & 556.4 \\
PTFE/graphene-4 & 488.4 & 524.3 & 551.7 \\
PTFE/ $\mathrm{Al}_{2} \mathrm{O}_{3}-4$ & 485.2 & 518.7 & 544.1 \\
PTFE/BA80-4 & 483.9 & 518.1 & 540.9 \\
PTFE/MG70-4 & 464.3 & 516.2 & 545.3 \\
\hline
\end{tabular}

Table 7. The temperatures in case of $1 \%, 10 \%$ and $50 \%$ mass losses in nitrogen atmosphere measured by TGA.

\begin{tabular}{cccc}
\hline Materials & $\begin{array}{c}\text { Temperature at a 1\% } \\
\text { Mass Loss }\left({ }^{\circ} \mathbf{C}\right)\end{array}$ & $\begin{array}{c}\text { Temperature at a 10\% } \\
\text { Mass Loss }\left({ }^{\circ} \mathbf{C}\right)\end{array}$ & $\begin{array}{c}\text { Temperature at a 50\% } \\
\text { Mass Loss }\left({ }^{\circ} \mathbf{C}\right)\end{array}$ \\
\hline PTFE & 492.8 & 528.2 & 556.7 \\
PTFE/graphene-4 & 488.4 & 524.4 & 555.5 \\
PTFE/ $\mathrm{Al}_{2} \mathrm{O}_{3}-4$ & 482.7 & 526.3 & 565.6 \\
PTFE/BA80-4 & 479.5 & 513.0 & 546.6 \\
PTFE/MG70-4 & 484.6 & 527.6 & 558.6 \\
\hline
\end{tabular}

\section{Conclusions}

In this research, the thermal and decomposition analyses of neat PTFE, graphene-, $\mathrm{Al}_{2} \mathrm{O}_{3}{ }^{-}, \mathrm{BA} 80-$ and MG70-filled PTFE were conducted by using the high temperature production method.

The decompositions of the neat PTFE and the neat fillers during a sintering process were measured by TGA (maximum sintering temperature: $370^{\circ} \mathrm{C}$ ) followed by FTIR analysis: 
- As it was expected, the neat PTFE and the neat $\mathrm{Al}_{2} \mathrm{O}_{3}$ filler had high thermal stability during the sintering process.

- Most of the hydroxyl $(\mathrm{OH})$ functional groups of the BA80 filler survived in the applied sintering process.

- The thermal stability of MG70 was too low to be used in the sintered PTFE.

The decompositions of the filled PTFE materials during a sintering process were measured by TGA (maximum sintering temperature: $370^{\circ} \mathrm{C}$ ) followed by FTIR analysis:

- Low thermal stability was observed in case of the $\mathrm{Al}_{2} \mathrm{O}_{3}$-filled PTFE materials; the mass losses of these materials were remarkably higher than was expected from the results of the neat PTFE and $\mathrm{Al}_{2} \mathrm{O}_{3}$. This indicated that there was an interaction between the thermally stable PTFE and $\mathrm{Al}_{2} \mathrm{O}_{3}$ at $370^{\circ} \mathrm{C}$. The decomposition extent of these materials was increased, as the filler content increased.

- The sintering process with a $10 \mathrm{~h}$ dwelling time confirmed the low thermal stability of the $\mathrm{Al}_{2} \mathrm{O}_{3}$-filled PTFE materials. These materials were sensitive to the applied dwelling time at the maximum sintering temperature, unlike the neat PTFE or neat $\mathrm{Al}_{2} \mathrm{O}_{3}$. The FTIR spectra did not confirm the existence of $\mathrm{AlF}_{3}$ (Equation (1)). Therefore, it was supposed that the $\mathrm{Al}_{2} \mathrm{O}_{3}$ filler catalysed the decomposition of the PTFE matrix.

Author Contributions: Conceptualization, L.F.T., P.D.B. and G.S.; investigation, L.F.T.; writing of the original draft preparation, L.F.T.; writing of review and editing, L.F.T., P.D.B. and G.S.; supervision, L.F.T., P.D.B. and G.S. All authors have read and agreed to the published version of the manuscript.

Funding: L.F.T. acknowledges the financial support received through ÚNKP-18-3-I-BME-176 New National Excellence Program of the Ministry of Human Capacities. This research was supported by the BME-Nanotechnology FIKP grant (BME FIKP-NAT).

Acknowledgments: This research was performed under a cooperative effort between Ghent University (Belgium) and Budapest University of Technology and Economics (Hungary). The authors would like to thank 3M Company and Azelis for their material support. The authors acknowledge the efforts of József Karger-Kocsis ${ }^{\text {tp }}$, Tamás Igricz and Balázs Pinke from Budapest University of Technology and Economics and Jacob Sukumaran and Dieter Fauconnier from Ghent University.

Conflicts of Interest: The authors declare no conflict of interest.

\section{References}

1. Song, P.; Wang, C.; Chen, L.; Zheng, Y.; Liu, L.; Wu, Q.; Huang, G.; Yu, Y.; Wang, H. Thermally stable, conductive and flame-retardant nylon 612 composites created by adding two-dimensional alumina platelets. Compos. Part A 2017, 97, 100-110. [CrossRef]

2. Liang, J.Z. Effects of tension rates and filler size on tensile properties of polypropylene/ graphene nano-platelets composites. Compos. Part B 2019, 167, 241-249. [CrossRef]

3. Rodriguez, V.; Sukumaran, J.; Schlarb, A.K.; De Baets, P. Reciprocating sliding wear behaviour of PEEK-based hybrid composites. Wear 2016, 362-363, 161-169. [CrossRef]

4. Gumede, T.P.; Luyt, A.S.; Müller, A.J. Review on PCL, PBS, and PCL/PBS blends containing carbon nanotubes. Express Polym. Lett. 2018, 12, 505-529. [CrossRef]

5. Jun, Y.S.; Um, J.G.; Jiang, G.; Yu, A. A study on the effects of graphene nano-platelets (GnPs) sheet sizes from a few to hundred microns on the thermal, mechanical, and electrical properties of polypropylene (PP)/GnPs composites. Express Polym. Lett. 2018, 12, 885-897. [CrossRef]

6. Pan, C.; Kou, K.; Zhang, Y.; Li, Z.; Wu, G. Enhanced through-plane thermal conductivity of PTFE composites with hybrid fillers of hexagonal boron nitride platelets and aluminum nitride particles. Compos. Part B 2018, 153, 1-8. [CrossRef]

7. Pan, C.; Zhang, J.; Kou, K.; Zhang, Y.; Wu, G. Investigation of the through-plane thermal conductivity of polymer composites with in-plane oriented hexagonal boron nitride. Int. J. Heat. Mass. Tran. 2018, 120, 1-8. [CrossRef]

8. Cui, J.; Zhou, Z.; Jia, M.; Chen, X.; Shi, C.; Zhao, N.; Guo, X. Solid Polymer Electrolytes with Flexible Framework of SiO2 Nanofibers for Highly Safe Solid Lithium Batteries. Polymers 2020, 12, 1324. [CrossRef]

9. Kalácska, G. An engineering approach to dry friction behaviour of numerous engineering plastics with respect to the mechanical properties. Express Polym. Lett. 2013, 7, 199-210. [CrossRef] 
10. Aderikha, V.N.; Krasnov, A.P.; Shapovalov, V.A.; Golub, A.S. Peculiarities of tribological behavior of low-filled composites based on polytetrafluoroethylene (PTFE) and molybdenum disulphide. Wear 2014, 320, 135-142. [CrossRef]

11. Makowiec, M.E.; Blanchet, T.A. Improved wear resistance of nanotube- and other carbon-filled PTFE composites. Wear 2017, 374-375, 77-85. [CrossRef]

12. Khedkar, J.; Negulescu, I.; Meletis, E.I. Sliding wear behavior of PTFE composites. Wear 2002, 252, 361-369. [CrossRef]

13. Krick, B.A.; Ewin, J.J.; Blackman, G.S.; Junk, C.P.; Sawyer, W.G. Environmental dependence of ultra-low wear behavior of polytetrafluoroethylene (PTFE) and alumina composites suggests tribochemical mechanisms. Tribol. Int. 2012, 51, 42-46. [CrossRef]

14. Padenko, E.; van Rooyen, L.J.; Wetzel, B.; Karger-Kocsis, J. “Ultralow” sliding wear polytetrafluoro ethylene nanocomposites with functionalized graphene. J. Reinf. Plast. Compos. 2016, 35, 892-901. [CrossRef]

15. Kandanur, S.S.; Rafiee, M.A.; Yavari, F.; Schrameyer, M.; Yu, Z.Z.; Blanchet, T.A.; Koratkar, N. Suppression of wear in graphene polymer composites. Carbon 2012, 50, 3178-3183. [CrossRef]

16. Harris, K.L.; Pitenis, A.A.; Sawyer, W.G.; Krick, B.A.; Blackman, G.S.; Kasprzak, D.J.; Junk, C.P. PTFE tribology and the role of mechanochemistry in the development of protective surface films. Macromolecules 2015, 48, 3739-3745. [CrossRef]

17. Padenko, E.; van Rooyen, L.J.; Karger-Kocsis, J. Transfer film formation in PTFE/oxyfluorinated graphene nanocomposites during dry sliding. Tribol. Lett. 2017, 65, 1-11. [CrossRef]

18. Karger-Kocsis, J.; Lendvai, L. Polymer/boehmite nanocomposites: A review. J. Appl. Polym. Sci. 2017, 45573, 1-31. [CrossRef]

19. Pedrazzoli, D.; Khumalo, V.M.; Karger-Kocsis, J.; Pegoretti, A. Thermal, viscoelastic and mechanical behavior of polypropylene with synthetic boehmite alumina nanoparticles. Polym. Test. 2014, 35, 92-100. [CrossRef]

20. Hobosyan, M.A.; Kirakosyan, K.G.; Kharatyan, S.L.; Martirosyan, K.S. PTFE- $\mathrm{Al}_{2} \mathrm{O}_{3}$ reactive interaction at high heating rates. J. Therm. Anal. Calorim. 2015, 119, 245-251. [CrossRef]

21. Chen, S.; Xin, Y.; Zhou, Y.; Zhang, F.; Ma, Y.; Zhou, H.; Qi, L. Branched CNT @ $\mathrm{SnO}_{2}$ nanorods @ carbon hierarchical heterostructures for lithium ion batteries with high reversibility and rate capability. J. Mater. Chem. A 2014, 2, 15582-15589. [CrossRef]

22. Liu, C.; Shih, K.; Gao, Y.; Li, F.; Wei, L. Dechlorinating transformation of propachlor through nucleophilic substitution by dithionite on the surface of alumina. J. Soils. Sediments 2012, 12, 724-733. [CrossRef] 